\title{
SEASONAL FLIGHT ACTIVITY AND SOME ATTRACTANTS POTENCY ON THE RED PALM WEEVIL, Rhynchophorus ferrugineus USING PHEROMONES TRAP AT FAYOUM GOVERNORATE, EGYPT.
}

Solaiman, R. H. A. ${ }^{*}$ and Nadia A. Abd El-Latif*

"Dept. Plant Protection, College of Agriculture , Fayoum University, "Dept. wood borers Plant Protection Research Institute, A.R.C., Ministry of Agriculture.

\begin{abstract}
The present study was conducted at a private date palm farm about 125 feddans at Fayoum district, Fayoum governorate to study Seasonal flight activity of adult Rhynchophorus ferrugineus Oliv. for one year between 23 October 2012 and 24 September 2013. Two synthetic aggregation pheromones were used in this study, the first pheromone was Ferrolure+ and the second pheromone was Rhyncap. The other attractants were ethyl acetate, date palm fruits and synthetic kairomone. Results showed that the number of weevils captured in traps recorded 4 flight activity periods. The first period extended from Oct. 23 to mid Jan. with peak 35 weevils $/ 5$ traps/ week during the early of December. The $2^{\text {nd }}$ flight activity period was from mid Jan. to the $4^{\text {th }}$ week of April with peak 31 weevils / 5 traps. The $3^{\text {rd }}$ flight activity period extended from $4^{\text {th }}$ week of April to $4^{\text {th }}$ week of July and recorded the two highest peaks 48 and 58 weevils $/ 5$ traps during $1^{\text {st }}$ and $3^{\text {rd }}$ week of May. Afterwards the population increased to record the $4^{\text {th }}$ flight activity period with peak 21 weevils $/ 5$ traps through $3^{\text {rd }}$ week of September. The sex ratio was $3: 1$ for females and males, respectively.. The pest recorded 4 generations per year. The simple correlation between weather factors and population of total flight period activity was insignificantly negative with maximum and minimum temperatures while insignificantly positive with $\mathrm{RH} \%$.

The traps baited with Ferolure+ plus date fruits caught the highest number of weevils followed by the traps baited with Ferrolure+ plus ethyl acetate ; both Ferrolure+ and Rhyncap alone where the captured weevils recorded 399, 301, 100 and 51 weevils/3 traps / 16 weeks, respectively. Traps baited with ethyl acetate plus date palm fruits captured a few weevils as compared with that baited with the pheromone combined with Ethyl acetate and date palm fruits or pheromones alone, it captured 9 weevils. Meanwhile, no adult weevils were responded to the traps baited with ethyl acetate or synthetic kairomone alone without aggregation pheromone. Results showed that adult weevils preferred the traps placed in the east direction where it attracted the highest number (275 weevils/3 traps /10 weeks). While the least number of captured weevils were recorded in the traps in south direction (120 weevils/3traps/10 weeks).
\end{abstract}

Keywords: Rhynchophorus ferrugineus; Flight activity; Aggregation pheromones; Ferrolure+; Rhyncap; Captured weevils.

\section{INTRODUCTION}

The red palm weevil, Rhynchophorus ferrugineus Oliv. is a lethal pest of palms and reported to attack 17 palm species worldwide including Phoenix dactylifera in several middle eastern countries where it is moved to Africa and Europe Faleiro (2006). Red palm weevil is a dreadful pest that attacks coconut plants in India. Trapping adult weevils help to reduce its population in an area Justin et al. ( 2008 ). Studies on seasonal flight activity of the red 
palm weevil were carried out by several authors such as (El-Garhy 1996; ElSebay 2003; Krishnakumer and Mahesware 2003 and Abe et al. 2009).

In tropical America, Ohlschlager et al. (1993) found that traps baited with insecticides treated palm stem pieces or sugarcane plus pheromone were more effective in catch of Rhynchophorus palmarium , where it captured 6 to 30 times more weevils than traps containing pheromone or treated sugarcane alone. More weevils captured in bucket traps placed at the ground than at height 1.7 or $3.1 \mathrm{~m}$.

Gomez et al. (2008) observed that in the presence of light, $62.5 \%$ of females prefer the trap to palm while $60 \%$ of the males prefer the palm. Jaffe et al. (1993) mentioned that although ethanol, ethyl acetate and isoamyl acetate were attractive to adult $R$. palmarium $\mathrm{L}$. in the laboratory. In the field the chemical compounds either presented alone or as mixture did not attract the weevil. Giblin et al. (1997) in Colombia, found that traps baited with stereoisomeric mixture of 4-methyl-5-nonanol plus sugarcane captured more weevils of Dynamis borassi F. than traps baited 4-methyl-5-nonanol or sugarcane alone. They suggested that pheromone and plant volatiles are synergistically attractive. Faleiro and Chellapan (1999) in India, mentioned that food baited pheromone traps have been effectively used to monitor and captures of weevil were female dominated.

The present study aims to know the flight activity of adult $R$. ferrugineus; the effect of weather factors on this activity; comparing the potency of different attractants and the effect of trap directions.

\section{MATERIALS AND METHODS}

\section{Trap Attractants}

Water white plastic bucket traps were used in the field experiments. Each trap (Fig. 1) consists of plastic container $(27 \mathrm{~cm}$ height $\times 28.5 \mathrm{~cm}$ diameter). Four holes (4 $\mathrm{cm}$ in diameter) were cut on the opposite sides of the container at $12 \mathrm{~cm}$ height of container bottom. Another 2 holes with the same measure on the cover to allow weevil entry into the trap.

Two synthetic aggregation pheromones were used in this study, the first pheromone was Ferrolure+ obtained from ChemTica International S.A. company and consists of 4-methyl-5-nonanol and 4-methyl -5-nonanone with ratio 9:1 and the second pheromone was Rhyncap obtained from Sedq company, Spain ). The other attractants were ethyl acetate and date palm fruits. All attractants were stored in refrigerator until use. Ethyl acetate lure consisted of $50 \mathrm{ml}$ of ethyl acetate solution $95 \%$ purity was put in dark plastic bottle. The cap of bottle was perforated and hung in trap. Aggregation pheromones were changed at 8 weeks intervals while date palm fruits were replaced in traps weekly.

\section{Field experiments}

All experiments were carried out at a private date palm farm about 125 feddans at Fayoum district, Fayoum governorate between 23 October 2012 and 24 September 2013. Farm cultivated with sewy variety. Also, under palm trees the area was cultivated with clover and wheat in winter and sorghum in summer season. 


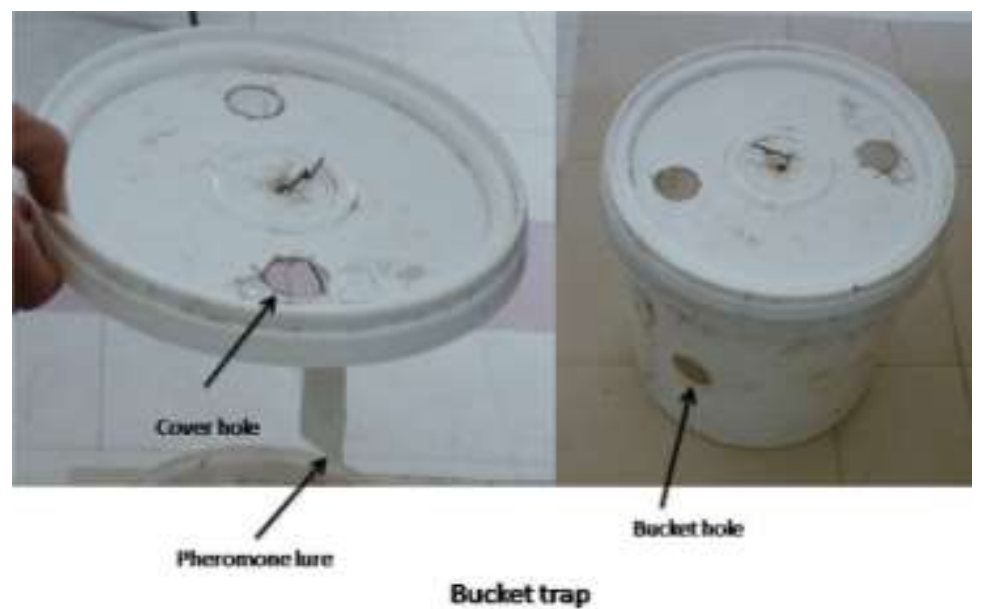

Fig.1. Water plastic bucket trap

\section{Seasonal flight activity of adults}

To study the flight activity of adults, five water plastic traps were provided with pheromone lure Ferrolure + plus date palm fruits and buried in the ground under the planted date palm trees. Checks on the traps were carried out weekly to count and record the captured weevils according to its sex, at the same time provided it with water and 200 grams of date fruits. Simple correlation value was estimated for the relation between $R$. ferrugineus populations and the three weather factors (weekly means of max. and min. temperatures and $\mathrm{RH} \%$ ).

\section{Effect of trap directions}

Effect of trap directions was evaluated by visually dividing the farm into for quadrants (east, west, north and south) and placing three water plastic trap in each direction of farm at $200 \mathrm{~m}$ distance between the traps (Fig. 2). Traps were investigated weekly to count captured weevils and provide traps with water, date palm fruits and soap. This experiment was conducted from the beginning of flight activity for 10 weeks.

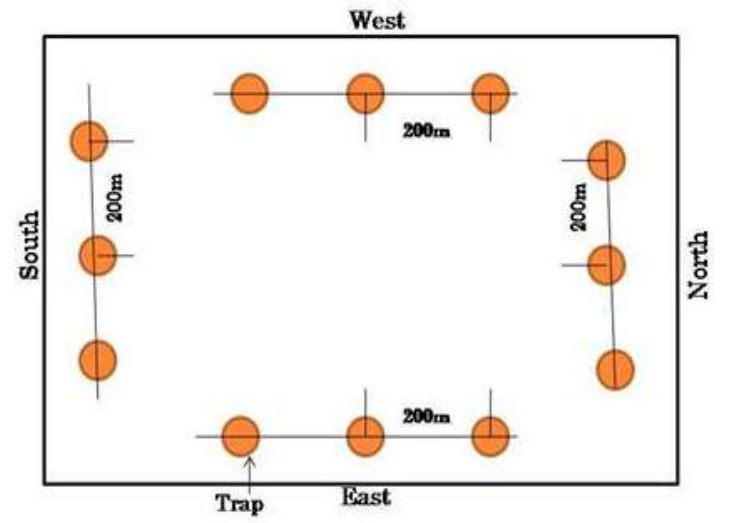

Fig.2. Illustrative sketch for traps distribution in the farm. 


\section{Potency of attractants}

To compare the potency of different attractants, the following treatments were used Ferolure+, Ferolure+ plus ethyl acetate, Ferolure+ plus date palm fruits, Rhyncap, Ethyl acetate, synthetic Kairomone, and Ethyl acetate plus date palm fruits and each treatment replicated 3 times. Each trap was baited with one of the above mentioned treatments. Traps were provided with water and soap then buried in the soil. Traps were distributed in the farm with starting of flight activity period during March 5 and continued till June 18. Captured weevils in the traps were collected weekly, separated according to sex and counted. Trap position was replaced each 2 weeks, and pheromone lures were replaced with other newly ones each 8 weeks. The data for the second and third experiments were analyzed using analysis of variance ANOVA by using SPSS program version 10 , followed by mean separation using Duncan's multiple range test.

\section{RESULTS}

\section{Seasonal flight activity}

Data in table (1) show that the number of weevils captured in traps recorded 4 flight activity periods. The first period extended from October 23 to mid Jan. with peak (35 weevils/5 traps/ week) throughout the early of December. After that the population increased to record the second flight activity period which extended from mid Jan. to the 4th week of April with peak (31 weevils / 5 traps) during $3^{\text {rd }}$ week of March. The $3^{\text {rd }}$ flight activity period extended from $4^{\text {th }}$ week of April to $4^{\text {th }}$ week of July and recorded the two highest peaks 48 and 58 weevils / 5 traps during $1^{\text {st }}$ and $3^{\text {rd }}$ week of May.

During $4^{\text {th }}$ period of activity which extended from July 23 to Sept. 24 the population of weevil decreased to appear in relatively little number and increased again to record lowest peak with 21 weevils / 5 traps through $3^{\text {rd }}$ week of September. Concerning sex ratio and number of generations, it found that the number of captured females were generally 3 times as that of males. The pest recorded 4 generations per year. 
Table 1. Number of red palm weevils captured in traps baited with Ferrolure+ plus date palm fruits at Fayoum district, Fayoum governorate, Egypt, during Oct.23/2012 to Sept. 24/2013 season.

\begin{tabular}{|c|c|c|c|c|c|c|c|}
\hline \multirow{3}{*}{$\begin{array}{l}\text { Date of } \\
\text { inspection }\end{array}$} & \multicolumn{4}{|c|}{ No. of baited weevils/ 5 traps } & \multicolumn{3}{|c|}{ Weather factors } \\
\hline & \multicolumn{3}{|c|}{ R. ferrugineus } & \multirow{2}{*}{$\begin{array}{c}\text { Sphenophous } \\
\text { piceus }\end{array}$} & \multicolumn{2}{|c|}{ Temp. $^{\circ}$} & \multirow{2}{*}{$\begin{array}{l}\text { Mean } \\
\text { RH \% }\end{array}$} \\
\hline & 우 & $0^{\pi}$ & total & & Max. & Min. & \\
\hline $23 / 10 / 2012$ & 11 & 03 & 14 & 00 & 27.5 & 14.9 & 57.0 \\
\hline $30 / 10$ & 10 & 05 & 15 & 00 & 28.3 & 15.5 & 56.0 \\
\hline $6 / 11$ & 16 & 05 & 21 & 00 & 24.4 & 11.2 & 56.0 \\
\hline $13 / 11$ & 13 & 03 & 16 & 00 & 23.7 & 12.0 & 60.0 \\
\hline $20 / 11$ & 10 & 03 & 13 & 00 & 24.3 & 9.3 & 58.0 \\
\hline $27 / 11$ & 16 & 02 & 18 & 00 & 24.7 & 10.4 & 56.0 \\
\hline $4 / 12$ & 22 & 13 & 35 & 00 & 24.7 & 9.3 & 59.0 \\
\hline $11 / 12$ & 06 & 01 & 07 & 00 & 23.9 & 10.9 & 68.0 \\
\hline $18 / 12$ & 05 & 01 & 06 & 00 & 24.2 & 11.5 & 68.0 \\
\hline $25 / 12$ & 00 & 01 & 01 & 00 & 23.9 & 10.3 & 68.0 \\
\hline $1 / 1 / 2013$ & 02 & 01 & 03 & 00 & 23.0 & 8.3 & 65.0 \\
\hline $8 / 1$ & 03 & 00 & 03 & 00 & 22.1 & 9.3 & 60.0 \\
\hline $15 / 1$ & 00 & 00 & 00 & 00 & 17.8 & 5.7 & 59.0 \\
\hline $22 / 1$ & 03 & 01 & 04 & 00 & 19.1 & 4.5 & 58.0 \\
\hline $29 / 1$ & 07 & 03 & 10 & 00 & 19.1 & 6.8 & 56.0 \\
\hline $5 / 2$ & 12 & 01 & 13 & 00 & 20.2 & 6.6 & 56.0 \\
\hline $12 / 2$ & 11 & 05 & 16 & 00 & 20.8 & 6.2 & 51.0 \\
\hline $19 / 2$ & 13 & 06 & 19 & 00 & 20.4 & 7.7 & 55.0 \\
\hline $26 / 2$ & 17 & 11 & 28 & 00 & 24.7 & 12.0 & 57.0 \\
\hline $5 / 3$ & 17 & 08 & 25 & 21 & 26.3 & 9.7 & 54.0 \\
\hline $12 / 3$ & 15 & 08 & 23 & 06 & 23.7 & 7.9 & 51.0 \\
\hline $19 / 3$ & 20 & 11 & 31 & 32 & 24.6 & 8.9 & 55.0 \\
\hline $26 / 3$ & 06 & 01 & 07 & 24 & 30.6 & 11.5 & 51.0 \\
\hline $2 / 4$ & 11 & 07 & 18 & 14 & 25.7 & 10.5 & 54.0 \\
\hline $9 / 4$ & 22 & 03 & 25 & 09 & 27.9 & 10.6 & 50.0 \\
\hline $16 / 4$ & 21 & 09 & 30 & 11 & 29.4 & 13.1 & 52.0 \\
\hline $24 / 4$ & 11 & 02 & 13 & 00 & 24.2 & 15.3 & 50.0 \\
\hline $30 / 4$ & 27 & 15 & 42 & 14 & 32.0 & 14.8 & 48.0 \\
\hline $7 / 5$ & 36 & 12 & 48 & 03 & 32.1 & 17.0 & 50.0 \\
\hline $14 / 5$ & 17 & 06 & 23 & 05 & 31.1 & 15.0 & 51.0 \\
\hline $21 / 5$ & 47 & 11 & 58 & 07 & 32.0 & 15.4 & 50.0 \\
\hline $28 / 5$ & 19 & 03 & 22 & 02 & 37.3 & 19.6 & 49.0 \\
\hline $4 / 6$ & 09 & 04 & 13 & 02 & 37.9 & 19.3 & 49.0 \\
\hline $11 / 6$ & 11 & 05 & 16 & 01 & 34.8 & 19.6 & 49.0 \\
\hline $18 / 6$ & 06 & 02 & 08 & 05 & 33.5 & 20.0 & 54.0 \\
\hline $25 / 6$ & 07 & 00 & 07 & 24 & 38.0 & 20.0 & 49.0 \\
\hline $2 / 7$ & 05 & 00 & 05 & 16 & 38.7 & 22.3 & 51.0 \\
\hline $9 / 7$ & 01 & 01 & 02 & 13 & 36.7 & 24.0 & 47.0 \\
\hline $16 / 7$ & 04 & 00 & 04 & 05 & 35.5 & 24.2 & 47.0 \\
\hline $23 / 7$ & 01 & 00 & 01 & 03 & 35.9 & 23.2 & 47.0 \\
\hline $30 / 7$ & 01 & 01 & 02 & 01 & 39.9 & 24.2 & 45.0 \\
\hline $6 / 8$ & 08 & 02 & 10 & 03 & 38.1 & 21.6 & 51.0 \\
\hline $13 / 8$ & 05 & 00 & 05 & 01 & 36.6 & 21.5 & 46.0 \\
\hline $20 / 8$ & 02 & 00 & 02 & 00 & 39.1 & 22.4 & 51.0 \\
\hline $27 / 8$ & 02 & 00 & 02 & 01 & 39.7 & 23.1 & 57.0 \\
\hline $3 / 9$ & 05 & 00 & 05 & 02 & 38.1 & 21.6 & 53.0 \\
\hline $10 / 9$ & 07 & 04 & 11 & 05 & 37.0 & 23.3 & 43.0 \\
\hline $17 / 9$ & 14 & 07 & 21 & 06 & 37.5 & 23.9 & 430 \\
\hline $24 / 9$ & 06 & 00 & 06 & 00 & 37.8 & 25.0 & 43.0 \\
\hline Total & 540 & 187 & 727 & & & & \\
\hline
\end{tabular}


Data obtained in table (2) demonstrate the effect of weather factors on captured weevil population of $R$. ferrugineus. the effect of maximum temperature was insignificant throughout all activity periods except one period ( mid Jan. to April 24) where the effect was significantly positive with female and total population $(n=15, \quad r=0.59$ and 0.54 , respectively). Concerning minimum temperature, the simple correlation was significantly negative between min. temperature and each of female, male, and total captured weevils ( $r=0.73,0.75$ and 0.75 , respectively) during the $3^{\text {rd }}$ period of activity from April 24 to July 23 . The effect was insignificantly positive during the other activity periods. The effect of $\mathrm{RH} \%$ on female, male and total population was significantly positive $(r=0.77,0.82$ and 0.82 , respectively ) during the period from July 23 to September 24 , while it was insignificantly negative during the periods from October 23 to mid Jan. ; from mid Jan. to April 24 and insignificantly positive during the period from April 24 to July 23. The simple correlation between weather factors and population of total flight activity period was insignificantly negative with maximum and minimum temperatures while insignificantly positive with $\mathrm{RH} \%$. On the other hand, it found that traps baited with Ferolure+ plus date palm fruits captured other weevils species. It was identified as Shenophorus piceus Pall.(Curculionidae : coleopteran). The flight activity of this insect started with the beginning of March until mid Sept. it recorded three peaks, the first and highest peak was recorded during March 19 with 32 weevils/5traps. The second and lowest peak was recorded at the end of April with 14 weevils/5 traps,then the weevil population decreased till the $2^{\text {nd }}$ week of June and increased gradually again to reach the $3^{\text {rd }}$ peak during the $4^{\text {th }}$ week of June.

Table 2. Simple correlation values $(r)$ for relationship between $R$. ferrugineus weevils captured in traps baited with Ferolure+ plus date palm fruits and Max., Min. temperatures and RH\% during certain activity periods of 2012/2013.

\begin{tabular}{|c|c|c|c|c|c|}
\hline \multirow{2}{*}{ Flight activity period } & \multirow{2}{*}{$\mathbf{N}$} & \multirow{2}{*}{$\operatorname{sex}$} & \multicolumn{3}{|c|}{$\mathbf{r}$} \\
\hline & & & Max. & Min. & RH\% \\
\hline \multirow{3}{*}{$23 / 10 / 2012-15 / 1 / 2013$} & \multirow{3}{*}{13} & $\mathrm{~F}$ & 0.50 & 0.31 & -0.60 \\
\hline & & $M$ & 0.41 & 0.18 & -0.39 \\
\hline & & $\mathrm{T}$ & 0.49 & 0.20 & -0.55 \\
\hline \multirow{3}{*}{$15 / 1 / 2013-24 / 4 / 2013$} & \multirow{3}{*}{15} & $\mathrm{~F}$ & $0.59^{*}$ & 0.49 & -0.46 \\
\hline & & $M$ & 0.36 & 0.31 & -0.08 \\
\hline & & $\mathrm{T}$ & $0.54^{*}$ & 0.46 & -0.34 \\
\hline \multirow{3}{*}{ 24/4/2013- 23/7/2013 } & \multirow{3}{*}{14} & $\mathrm{~F}$ & -0.38 & $-0.73^{*}$ & 0.17 \\
\hline & & $M$ & -0.39 & $-0.75^{\star}$ & 0.07 \\
\hline & & $\mathrm{T}$ & -0.39 & $-0.75^{*}$ & 0.15 \\
\hline \multirow{3}{*}{ 23/7/2013-24/9/2013 } & \multirow{3}{*}{10} & $\mathrm{~F}$ & -0.30 & 0.07 & $0.77^{\star}$ \\
\hline & & $M$ & -0.18 & 0.24 & $0.82^{*}$ \\
\hline & & $\mathrm{T}$ & -0.26 & 0.13 & $0.82^{*}$ \\
\hline \multirow{3}{*}{$23 / 10 / 2012-24 / 9 / 2013$} & \multirow{3}{*}{49} & $\mathrm{~F}$ & -0.09 & -0.19 & 0.03 \\
\hline & & M & -0.17 & -0.26 & 0.11 \\
\hline & & $\mathrm{T}$ & -0.12 & -0.22 & 0.06 \\
\hline
\end{tabular}




\section{Effect of trap direction}

Data in table (3) show that adult weevils responded less to trap with a southern direction (120weevils/3traps/10 weeks) and displayed a certain preference for the east direction (275 weevils/3 traps /10 weeks). No attempt was made to investigate specific factors which may have caused this pheromone response pattern. Possibly, prevalence of careless and infested date palm trees in the east direction (1.5-2 Km apart from experiment area) may have been responsible for capture increasing in this direction. On the other hand, females were more captured in four directions where the sex percentages of females were $66.5,73.2,61.9$ and $63.3 \%$ for east, west, north and south directions, respectively according to the total captured weevils in each direction. Among directions the flight activity of females preferred east followed by west, while males preferred north and south directions. It found that traps in east direction were the most attractive to female, male and total weevils, followed by those of the west direction. Statistical analysis demonstrates no significant differences could be found between effect of north and south directions on captured males, females. The number of trapped females in east direction traps was significantly higher than those of north and south directions. The effect of trap direction on total number of captured weevils was insignificant among west, north and south, and between east and west directions, while it was significant between east and both north and south directions

Table 3. Influence of pheromone traps direction within farm on individual catches of $\boldsymbol{R}$. ferrugineus weevils.

\begin{tabular}{|c|c|c|c|c|c|c|c|c|c|c|c|c|}
\hline \multirow{3}{*}{$\begin{array}{l}\text { Catch } \\
\text { perio }\end{array}$} & \multicolumn{12}{|c|}{ No. of adult weevils attracted $/ 3$ trap /direction } \\
\hline & \multicolumn{3}{|c|}{ East } & \multicolumn{3}{|c|}{ West } & \multicolumn{3}{|c|}{ North } & \multicolumn{3}{|c|}{ South } \\
\hline & $\mathbf{M}$ & $\mathbf{F}$ & $\mathbf{T}$ & $\mathbf{M}$ & $\mathbf{F}$ & $\mathbf{T}$ & $\mathbf{M}$ & $\mathbf{F}$ & $\mathbf{T}$ & $\mathbf{M}$ & $\mathbf{F}$ & $\mathbf{T}$ \\
\hline $1^{\mathrm{st}}$ & 12 & 19 & 31 & 09 & 14 & 23 & 05 & 06 & 11 & 12 & 26 & 38 \\
\hline $2^{\text {nd }}$ & 16 & 26 & 42 & 07 & 28 & 35 & 04 & 04 & 08 & 14 & 14 & 28 \\
\hline $3^{\text {rd }}$ & 15 & 33 & 48 & 06 & 22 & 28 & 02 & 11 & 13 & 02 & 09 & 11 \\
\hline $4^{\text {th }}$ & 03 & 12 & 15 & 04 & 10 & 14 & 04 & 06 & 10 & 00 & 00 & 00 \\
\hline $5^{\text {th }}$ & 05 & 22 & 27 & 08 & 11 & 19 & 06 & 07 & 13 & 00 & 02 & 2 \\
\hline $6^{\text {th }}$ & 03 & 08 & 11 & 02 & 16 & 18 & 01 & 04 & 05 & 02 & 00 & 02 \\
\hline $7^{\text {th }}$ & 04 & 08 & 12 & 03 & 11 & 14 & 06 & 09 & 15 & 03 & 01 & 04 \\
\hline $8^{\text {th }}$ & 02 & 06 & 08 & 02 & 07 & 09 & 01 & 08 & 09 & 01 & 03 & 04 \\
\hline $9^{\text {th }}$ & 09 & 24 & 33 & 08 & 18 & 26 & 09 & 12 & 21 & 01 & 08 & 09 \\
\hline $10^{\text {th }}$ & 23 & 25 & 48 & 06 & 13 & 19 & 10 & 11 & 21 & 09 & 13 & 22 \\
\hline Total & 92 & 183 & 275 & 55 & 150 & 205 & 48 & 78 & 126 & 44 & 76 & 120 \\
\hline Mean & 9.2 & 18.3 & 27.5 & 5.5 & 15.0 & 20.5 & 4.8 & 7.8 & 12.6 & 4.4 & 7.6 & 12.0 \\
\hline \pm se & \pm 0.79 & \pm 1.03 & \pm 1.71 & \pm 0.29 & \pm 0.70 & \pm 0.85 & \pm 0.34 & \pm 0.32 & \pm 0.58 & \pm 0.58 & \pm 0.92 & \pm 1.44 \\
\hline * & 33.5 & 66.5 & & 26.8 & 73.2 & & 38.1 & 61.9 & & 36.7 & 63.3 & \\
\hline \multirow[t]{2}{*}{$\star \star *$} & \begin{tabular}{|l|l}
12.7 \\
\end{tabular} & 25.2 & & 7.6 & 20.7 & & 6.6 & 10.7 & & 6.1 & 10.5 & \\
\hline & \multicolumn{2}{|c|}{$\begin{array}{l}\text { East } \\
\text { West } \\
\text { North } \\
\text { South }\end{array}$} & $\begin{array}{c}92 \\
55 \\
48 \\
44\end{array}$ & $\begin{array}{l}M \\
b \\
b \\
b \\
a \\
a\end{array}$ & $\begin{array}{l}183 \\
150 \\
78 a \\
76\end{array}$ & & $\begin{array}{l}275 \\
205 \\
126 \\
120\end{array}$ & & & & & \\
\hline
\end{tabular}

* \% of catch for each direction, ${ }^{* *} \%$ of catch for all directions. 


\section{Attractants comparisons}

Results of attractant comparisons are based on weekly number of weevils captured in baited traps with different attractants during the abundant period of flight activity extended from March 5 and continued till June 18 . Results showed that the traps baited with Ferrolure+ plus date fruits caught the highest number of weevils followed by the traps baited with Ferrolure + plus ethyl acetate , Ferrolure + and Rhyncap alone where the captured weevils recorded 399, 302, 100 and 51 weevils per 3traps /16 weeks, respectively. Traps baited with ethyl acetate plus date palm fruits captured a few weevils as compared with that baited with the pheromone combined with ethyl acetate and date palm fruits or pheromones alone, where traps baited with ethyl acetate plus date fruit captured 9 weevils. Meanwhile, no adult weevils were responded to the traps baited with ethyl acetate or synthetic kairomone alone without aggregation pheromone. Concerning the effect of attractants on sex ratio of captured weevils, it found that traps baited with aggregation pheromone plus date palm fruits or ethyl acetate recorded the highest percentage of females with 32.29 and $23.69 \%$, respectively. (table4).

Table 4. Number of $R$. ferrugineus weevils captured in traps baited with different attractants during the period from early March to $3^{\text {rd }}$ week of June 2013.

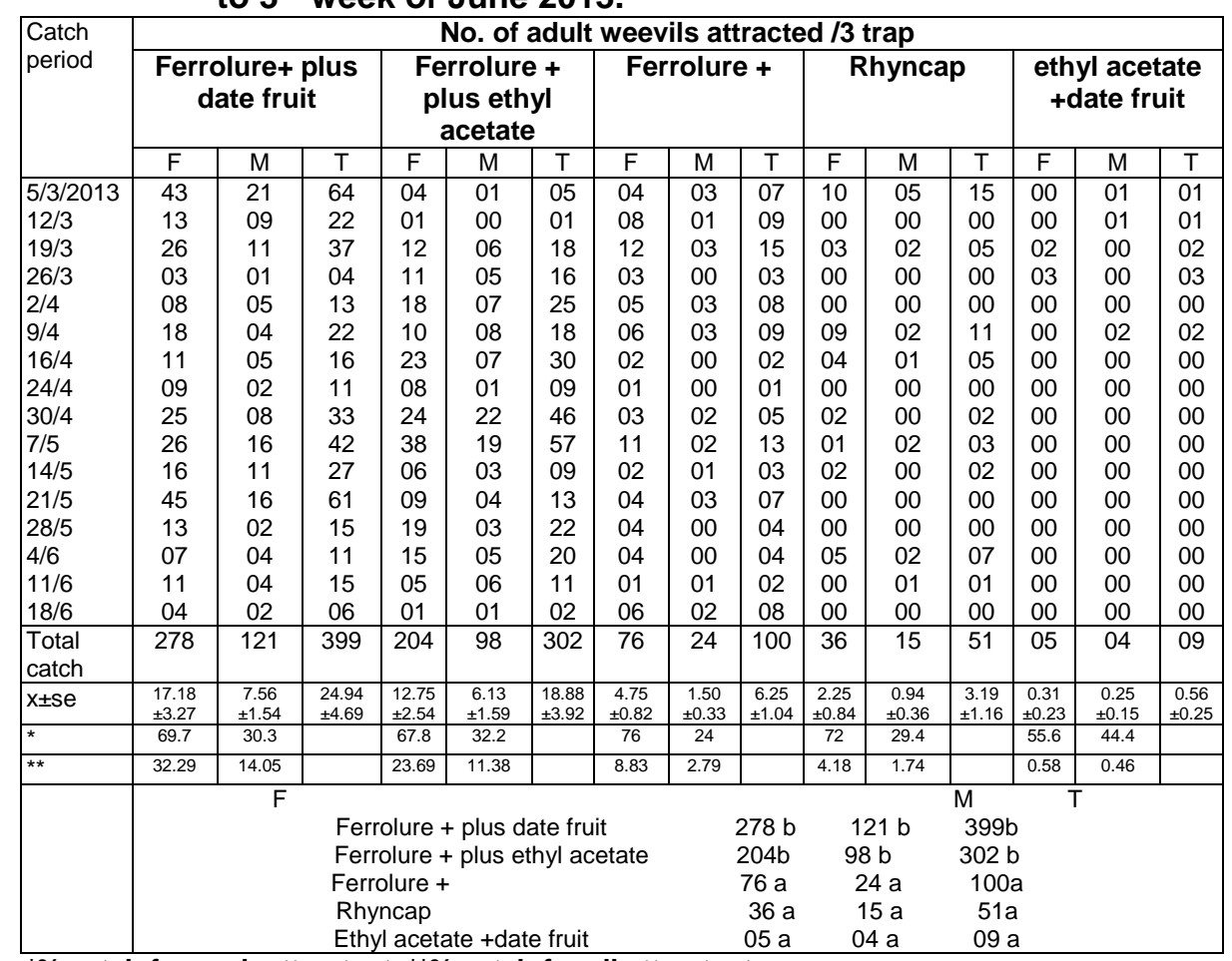


Among traps which captured significant weevils, traps baited with Ferrolure+ plus date palm fruits were the most preferred followed by those baited with Ferrolure+ plus ethyl acetate where the percentages of catch were 14.05 and $11.38 \%$, respectively. These data statistically demonstrate that traps baited with pheromone lure plus food volatiles (date palm fruits or ethyl acetate) catch significantly higher number of females, males and total number of weevils than those baited with pheromone or food volatile lures alone. No significant differences were found among catches of traps baited with Ferrolure+, Rhyncap and ethyl acetate plus date fruits. On the other hand, the effect of attractant was insignificant between Ferrolure+ plus date palm fruit and Ferrolure+ plus ethyl acetate.

\section{DISCUSSION}

\section{Seasonal flight activity}

Oehlschlager et al.(1993) found that sex ratio of females of Rhynchophorus palmarum nearly three times as males. Abbaas, 2000 mentioned that $R$. ferrugineus recorded from 5-6 peaks and had 4 generations per year. Also, he stated that the number of captured females were twice as that of males. Vidyasagar et al. (2000) found that A peak adult population trapped with pheromone traps was immediately after winter season during the two months of April and May and the smaller second peak was observed during October and November months before the onset winter. Kazem et al.( 2004) in Iran, stated that sex ratio of 4260 weevils were captured during the phero-trapping (249 days) was 2.8 female : 1 male. Abbas et al. (2006) mentioned that no significant differences could be found in rates of capture between males and females. Also, individuals of marked weevils released in date palm plantations migrated $1-7 \mathrm{Km}$ from releasing region. In Spain, Sansano-Javalayes et al. (2008) mentioned that the biggest number of captures was obtained during the three months of summer season. Also, they found that the average number of trapped female was 2.5 times as trapped males. Efficacy of pheromone lures recorded higher catches of weevil in March, April, May, June and July months Sujatha et al. (2010). Concerning effect of weather factors, Abbas (2000) found that there were positive and highly significant correlation between day temperature and number of captured weevils of $R$ ferrugineus, while the effect of $\mathrm{RH} \%$ was negative and highly significant.

\section{Directions and attractants comparisons}

In the present study traps baited with aggregation pheromone (Ferrolure+ ) plus date palm fruits or ethyl acetate trapped higher number of weevils than those baited with aggregation pheromones alone or ethyl acetate plus date palm fruits. This agree with several authors such as Jaffe et al. (1993) who noticed that although ethyl acetate alone or as a mixture with ethanol, pentane, hexanol and isopentanol were attractive to the palm weevil, R. palmarum in the laboratory did not attract weevils in the field. Oehlschlager et al. (1993) found that traps baited with insecticides treated palm stem pieces or sugarcane plus pheromone were more effective in catch of $R$. 
palmarium weevils than traps containing pheromone or treated sugarcane alone. Giblin-Davis et al. (1994) achieved good field trapping of Rhynchophorus cruentatus Fabricius with its aggregation pheromone plus ethyl acetate and a lesser degree with each of those compounds. Also, Gries et al. (1994) found that tissue was significantly more effective than synergistic kairomone (ethyl propionate) in attraction of Rhynchophorus phoenicus. Rochat et al. (2000) stated that a blend of ethanol-ethyl acetate in combination with an aggregation rhynchophorol showed synergy in the field to $R$. palmarum. Giblin-Davis et al. (2000) found that lures containing aggregation pheromone plus sugar cane captured more male and female of Rhabdoscelus obscures Boisduval than lures containing pheromone or sugarcane alone. Muniappan et al. (2004) mentioned that traps baited with lure of Australian $R$. obscures population in combination with ethyl acetate and cut of sugarcane captured significantly more than traps baited with Hawaiian $R$. obscures population. Also, traps baited with ethyl acetate and cut of sugarcane captured significantly fewer weevils than those baited with pheromone compounds.

Reddy et al.( 2005) mentioned that traps baited with pheromone combined with ethyl acetate caught significantly more weevils than traps baited with other semiochemical based lures. On contrasting, Giblin et al. (1996) mentioned that ethyl acetate was attractive as the raceme blend of the male aggregation pheromone at $3 \mathrm{mg} /$ day for Metamasius. Hemipterus sericeus Olivier (Curculionidae). Our results indicated that natural or chemical volatile compounds were attractive to weevils in the field only when supported by aggregation pheromone. Also, our results agree with Abbas ( 2000) who stated that the east direction was more abundant followed by west and north directions.

\section{REFERENCES}

Abbas, M. K. (2000): Studies on the red palm weevil, M. Sc. Faculty of Agriculture , Zagazig University.

Abbas, M. K.; B. S. Hanounik; S. A. Shahbad and A. S. Al-Bagham, (2006) : Aggregation pheromone traps, a major component of IPM strategy for the red palm weevil, Rhynchophorus ferrugineus in date palms (Coleoptera : Curculionidae ). Journal of pest Science, 79(2) : 69-73.

Abe, F.; K. Kunihiko and K. sone, (2009) : Life history of the red palm weevil, Rhynchophorus ferrugineus (Coleoptera : Dryphtoridae), in southern Japan. Florida Entomologest, 92(3) :221-225.

Duncan, D. B., (1955): Multiple range and multiple F. tests. Biom. 11:1-42.

El-Garhy, M. E. (1996) : Field evaluation of the aggregation pheromone of the red palm weevil, Rhynchophorus ferrugineus in Egypt. Brighton crop protection conference: pests \&diseases- 1996: vol.3 Proceeding of an international conference, Brighton, UK, 1059 - 1064.

El-Sebay, Y. (2003) : Ecological studies on the red palm weevil Rhynchophorus ferrugineus Oliv., (Coleoptera : Curculionidae) in Egypt. Egyptian Journal of Agricultural Research, 8(2) :523-529. 
Faleiro, J.R. (2006) : A review of the issues and management of the red palm weevil and date palm during the last one hundred year. International Journal of tropical insect science, 26(3) : 135-154.

Faleiro, J. R. and M. Chellapan, (1999): Attraction of red palm weevil, Rhynchophorus ferrugineus Oliv. to ferrugineu based pheromone lures in coconut gardens. J. tropical Agri. 37(1) :

Giblin-Davis, R. M., E. J. Pena; C. A. Ohlschlager and L. A. Perez, (1996) : Optimization of semiochemical based trapping of Metamasius hemipterus seiceus (Oliver) ( Coleoptera : Curculionidae). J. Chem. Ecol., 22, 1389-1410.

Giblin-Davis, R. M., J. T. Weissling; C. A. Oehlschlager and M. L. Gonzalez, (1994) : Field response of Rhynchophorus cruentatus ( coleopteran : Curculionidae ) to its aggregation pheromone and fermenting plant volatiles. Fl. Entomol , 77, 164-177.

Giblin-Davis, R. M., R. Gries; B. Crespi; N. L. Robertson; H. A. Hara; G. Gries; W. C. O'Brien and R. J. D. H. Pierce, ( 2000) : Aggregation pheromones of two geographical isolates of the new Guinea sugarcane weevil, Rhabdoscelus obscures. J. Chem. Ecol, 12, 27632780.

Giblin-Davis,R. M., R. Gries;G. Gries; E. Pena-Rojas; I. Pinzon; J. E. Pena; L. A. Perez; R. J. D. H. Pierce and C. A. Oehlshlager, ( 1997 ): Aggregation pheromone of palm weevil, Dynamis borassi. J. Chem. Ecol, 23(10) : 2287-2297.

Gomez-Vives, S., M. ferry; J. T. Martinez and G. Diaz-Espejo, (2008): Rehearsals in tunnel of wind for the improvement of the effectiveness of the pheromone traps of the red palm weevil, Rhynchophorus ferrugineus (Coleoptera : Dryophthoridae). Boletin de Sanidad Vegetal. Plagas, 34(1) : 151-161.

Gries, G., R. Gries; A. Perez ;M. L. Gonzalez R. J. D. H. Pierce; C. A. Oehlschlager; M. Rhainds; M. Zebeyou and B. Kouame, (1994) : Ethyl propionate synergistic Kairomone for African palm weevil Rhynchphorus phoenicis L. (Coleoptera : Curculionidae ). J. Chem. Ecol., 20, 889-897.

Jaffe, K., P. Sanchez; H. Cerda; V. J. Hernandez; R. Jaffe; N. Urdaneta; G. Guerra; R. Martinez and B. Miras (1993) : Chemical ecology of the palm weevil Rhynchophorus palmarum (L.)(Coleoptera : Curculiondae) : attraction to host plants and to a male produced aggregation pheromone. J. Chemical ecology, 19(8) : 1703-1720.

Justin, C. G.; M. Leelamathi; T. Thangaselvabai and N. B. S. Johnson, (2008) : Bioecology and management of the red palm weevil, Rhynchophorus ferrugineus Oliv. (Coleoptera : Curculionidae) on coconut - a review. Agricultural Reviews, 29(2) : 117-24.

Kazem, M., A. Avand-Faghih; D. Rochat, (2004) : Contribution of mass trapping with synthetic pheromone to integrated control of red palm weevil : Effect of trap density. Plant pests and diseases research institute, Tehran(Iran) 33pp. 
Krishnakumar, R. and P. Maheswari ( 2003 ) : Seasonal infestation of red palm weevil, Rhynchophorus ferrugineus (Oliv.) in Kerala. Insect of Environment, 9 (4) : 174-175.

Muniappan, M. R., J. Bamba; J. Cruz and G. V. P. Reddy, ( 2004) : Field response of Guam populations of the new Guinea sugarcane weevil, Rhabdoscelus obscures (Boisduval)(Coleoptera : Curculionidae). Micronesicta, 37(1) : 57-68.

Ohlschlager,A.; C. Chinchilla; L. Gonzáliz; L. Jirón; R. Mexón and B. Morgan, (1993) : Development of pheromone based trapping system for Rhynchophorus palmarium. J. Econ. Entomol., 86 : 1381 - 1382.

Reddy, P. V. G., Z. T. Cruz; J. Bamba and R. Muniappan, (2005) : Development of a semiochemical-based trapping method for the new Guinea sugarcane weevil, Rhabdoscelus obscures in Guam, Bkackwell Verlag, J. E. N., 129 (2) : 65-69.

Rochat, D., E.L. Nagnan; P. Meillour; R. J. Esteban Duron; C. Malosse; B. Perthuis; P. J. Morin and C. Descoins, (2000) : Identification of pheromone synergists in American palm weevil, Rhynchophorus ferrugineus, and attraction of related Dynamis borassi. J. Chem. Ecol., 26, 155-187.

Sansano-Javaloyes, M. P.; S. Gomez-Vives; M. ferry and G. Diaz-Espejo, (2008): Field trials for the improvement of the effectiveness of the trapping system of the red palm weevil, Rhynchophorus ferrugineus, Olivier (Coleoptera : Dryophthoridae). Boletin-de-Sanidad-Vegetal, Plagas, 34(1) : 135-145.

Sujatha, A., V. S. M. Chalam and S. Arularj, ( 2010) : Monitoring and management of Coleopteran pests of coconut through pheromone traps in Andhra Pradesh, Annals of plant protection Sciences, 18 (1) : 34-40.

Vidyasagar, P. S. P. V., H. Mohamed; A. R. Abozuhairah; E. O. AlMohanna and A. A. Al Saihati, (2000) : Impact of mass pheromone trapping on red palm weevil : adult population and infestation level in date palm gardens of Saudi Arabia. Planter 76 (891) : 347-355. 
نشـاط الطيـران الموســي وكفــاءة بعض الجاذبــات علـي سوسـة النخيـل الحمـراء

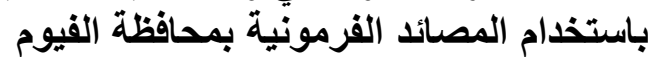
ربيع حسن عوض سليمان و نادية عبد المبالية الثفيع عبد الفيوم اللطيف

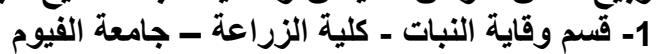

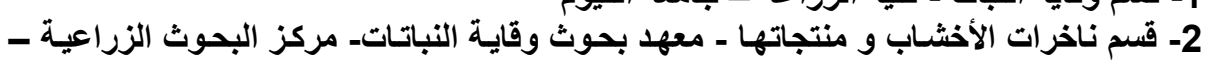

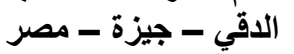

أجريت الدراسة في مزر عـة خاصة مساحتها حو الي 125 فدان في مركز الفيوم - محافظة الفيوم

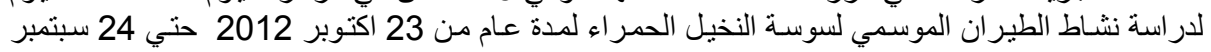
2013

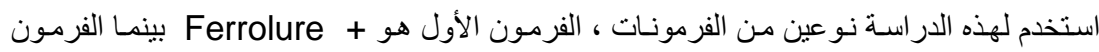

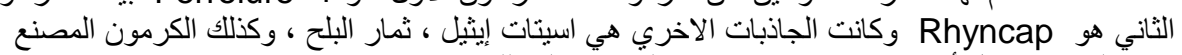

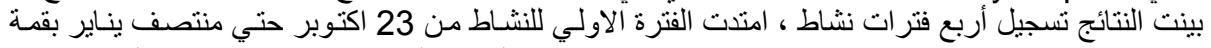

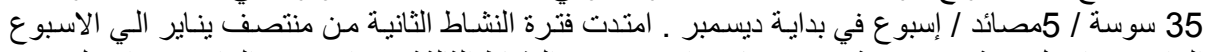

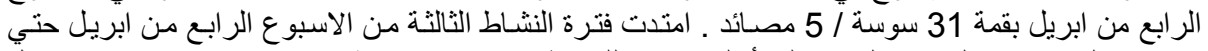

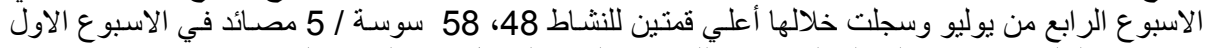

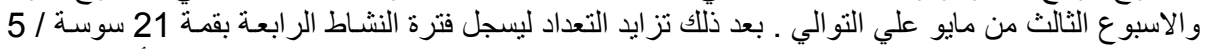

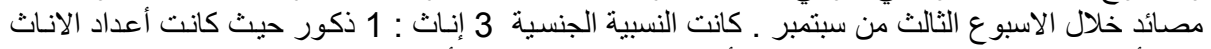

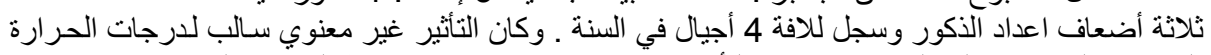

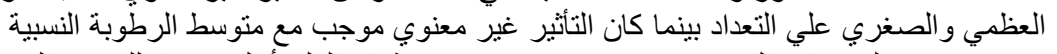

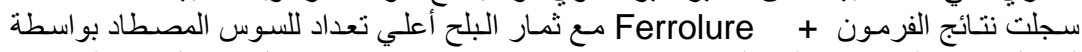

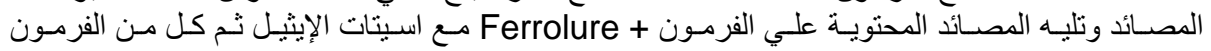

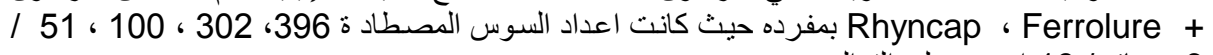
3 مصائد / 16 اسبوع علي التو الي بشرد

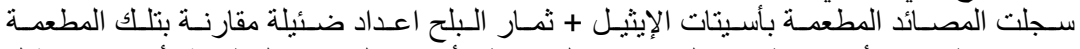

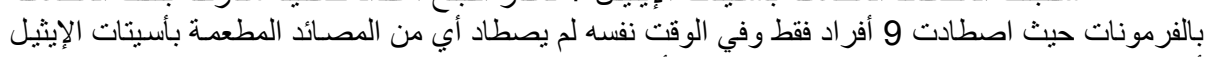

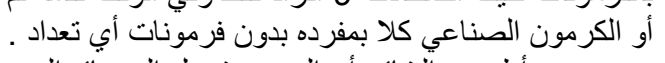

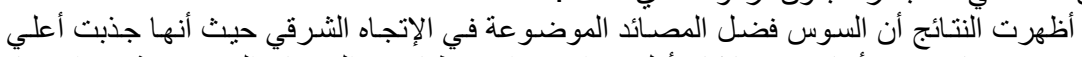

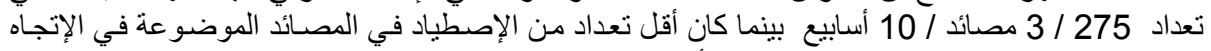
الجنوبي كانت 127 سوسة / 3 مصائد / 10 أسابيع

كلية الزراعة - جامعة المنصورة

كلية الزراعة - جامعة الاسكندرية

\author{
قام بتحكيم البحث \\ أ.د / على على عبد الهادى البحى \\ أ.د / نادر شاكر يوسف أبف
}

